\title{
The Institute of Musicology at the Ludwig Maximilian University during National Socialism: the Career of the Wagner Scholar Alfred Lorenz
}

\author{
WILLIAM KINDERMAN
}

\section{Introduction}

It was not originally my intention to research the history of the Institute of Musicology at the Ludwig Maximilian University in Munich. When I wrote a book about Wagner's final drama, Parsifal, ${ }^{1}$ however, I was obliged to engage with the legacy of Alfred Lorenz, whose monograph from 1933 was long regarded as the most comprehensive study of Parsifal. ${ }^{2}$ In order to best understand the work of Alfred Lorenz at the Institute of Musicology, we must briefly sketch the developing stages of Wagner reception. The history of Wagner reception after the composer's death in 1883 is a complex story with dark contours. Important events in this development unfolded in Munich, and particularly in the main building of the Ludwig Maximilian University, just a few steps away from the institute.

It makes sense to divide the history of Wagner reception in Germany into two broad periods: the 62 years from 1883 until 1945, and the 71 years from 1945 until 2016. The first of these periods was characterized by an increasingly narrow focus, whereby a Germanic-nationalist orientation assumed primacy. The important ways in which the Wagner family in Bayreuth contributed to this development was bound up with Cosima Wagner's ambition to control the Wagnerian legacy. She was unhappy about the performances of Wagner's first opera Die Feen (The Fairies) beginning in 1888 in Munich, and she was concerned as well about the opening at Munich in 1901 of the Prince Regent Theater, since that theater, based on plans by Max Littmann, bore a strong resemblance to the Festival Theater at Bayreuth.

A serious crisis for Cosima Wagner was the so-called "Parsifal theft," when that work was performed without her approval beginning in 1903 at the Metropolitan Opera in New York. In response, Cosima Wagner blacklisted all musicians and singers involved, blocking them from any subsequent participation at Bayreuth. The control of Bayreuth over Parsifal performances in countries that had signed the Geneva copyright agreement—the United States had not done so-elapsed in 1913, about a half-year before the outbreak of the First World War.

After the war the political situation in Germany became problematic and unstable, and in this

\footnotetext{
${ }^{1}$ This essay is based on a lecture held at the Institute of Musicology of the Ludwig Maximilian University in Munich on February 3, 2010. My book appeared as Wagner's 'Parsifal' in 2013, https://global.oup.com/academic/product/wagnersparsifal-9780195366921?cc=at\&lang=en\&; a related essay is "Wagners Parsifal als Kunst und Ideologie," in Richard Wagner. Persönlichkeit, Werk und Wirkung, ed. Helmut Loos (Leipzig: Sax Verlag, 2013), 109-117. A German version of this study appeared on the website of the Institute of Musicology in Munich https://lmuwi.hypotheses.org/alfred-lorenz-2. I thank Sebastian Bolz and Rainer Waubke for helpful comments.

${ }^{2}$ Lorenz, Der musikalische Aufbau von Richard Wagners 'Parsifal' (Berlin: Max Hesses Verlag, 1933; repr., Tutzing: Verlag Hans Schneider, 1966).
} 
situation the Bayreuth Circle (as it has become known) sought a redeeming figure, a kind of "Lohengrin."” What then transpired had much to do with two British-born inlaws of the Wagner clan. Houston Stewart Chamberlain, author of the best-selling book Die Grundlagen des neunzehnten Jahrhunderts (The Foundations of the Nineteenth Century), married Wagner's daughter Eva. Chamberlain lived long enough to hail Adolf Hitler at the Villa Wahnfried in 1923, and wished to recognize in him the rescuer of Germany following the defeat in World War I. Winifred Williams, an English orphan who had been adopted by the aging pianist Karl Klindworth and his wife in Berlin, became Siegfried Wagner's wife in 1915. She observed the aborted Munich Putsch in November 1923, and remained closely bound by friendship to Hitler. Even after World War II and to the end of her life she gave expression to her admiration for the Führer.

A well-known picture shows Hitler in the crowd at the Odeonsplatz in Munich in 1914, when the war began. More recently, the authenticity of this famous image has been called into question as possibly a product of Nazi propaganda. ${ }^{4}$

What was the situation in Wagner reception at Munich in 1933, immediately after Hitler's rise to power? For many years Wagner's legacy had been an object of dispute, but by this time it had become clear which side had won: the Germanic nationalist claim led into the so-called National Socialist agenda, in many essential respects already before 1933, if we take into account the political convictions of many contemporary participants, including the best-known university teacher and author who occupied himself during the 1920s and 30s with Wagner, Alfred Lorenz.

\section{Sources concerning Alfred Lorenz}

The documentary material about Lorenz that I present here is based in part on sources held at the university archives in Munich/Freimann, where I conducted research. ${ }^{5}$ These files are rich and detailed, since Lorenz came to his university position at a mature age and he repeatedly strove to improve his conditions or prolong his teaching activity. There are consequently several versions of his CV held in the archives as well as extensive correspondence with the university administration. Following his second dissertation (Habilitation) completed at the Institute of Musicology at the Ludwig Maximilian University in 1926, Lorenz became an honorary professor, and he continued to teach until his final illness in 1938, when he was 70 years old. He died in 1939 at about the time the war began.

Alfred Lorenz was born on July 11, 1868 in Vienna, where his father, the historian Ottokar Lorenz, was professor at the University of Vienna. As a young man, Alfred Lorenz studied conducting and musicology in Berlin. From 1888 until 1890 he was head of the Academic Wagner Association in Berlin, and held lectures for that organization. In 1898 he became second conductor and in 1904 first conductor in service of Duke Alfred of Saxony-Coburg-Gotha. His repertoire centered on the works of Wagner as well as the operas and tone poems of Richard Strauss. Lorenz remained the General Music Director of the Theater at Coburg-Gotha until 1920.

Here is a photograph of Alfred Lorenz from his Coburg period (Plate 1). The second image shows Lorenz during his time in Munich when he taught at the Institute of Musicology (Plate 2).

\footnotetext{
${ }^{3}$ For a study of the Bayreuth group (Bayreuther Kreis) as a "literary-ideological circle," see especially Winfried Schüler, Der Bayreuther Kreis von seiner Entstehung bis zum Ausgang der wilhelminischen Ära: Wagnerkult und Kulturreform im Geiste völkischer Weltanschauung (Munich: Aschendorff, 1971).

${ }^{4}$ See https://www.welt.de/kultur/article10284920/Beruehmtes-Hitler-Foto-moeglicherweise-gefaelscht.html.

${ }^{5}$ I thank archivist Claudius Stein for granting access to materials in the University Archive and for permission to reproduce selected documents in this article.
} 


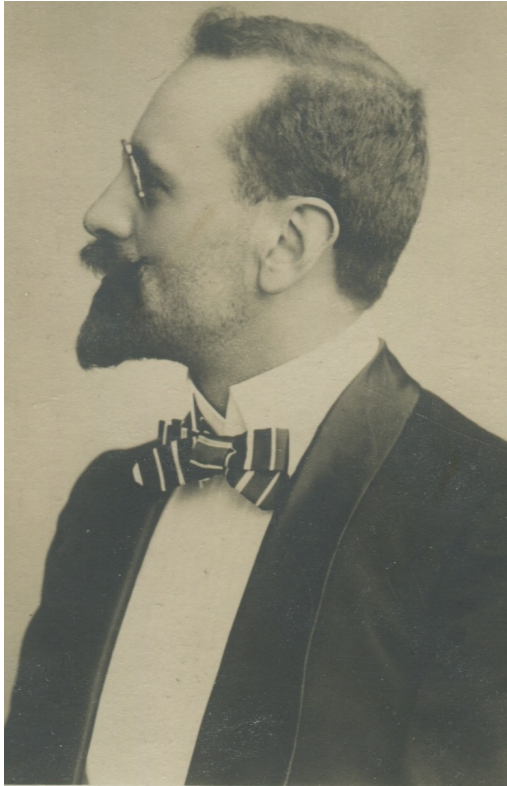

Plate 1: Alfred Lorenz (author's private collection).

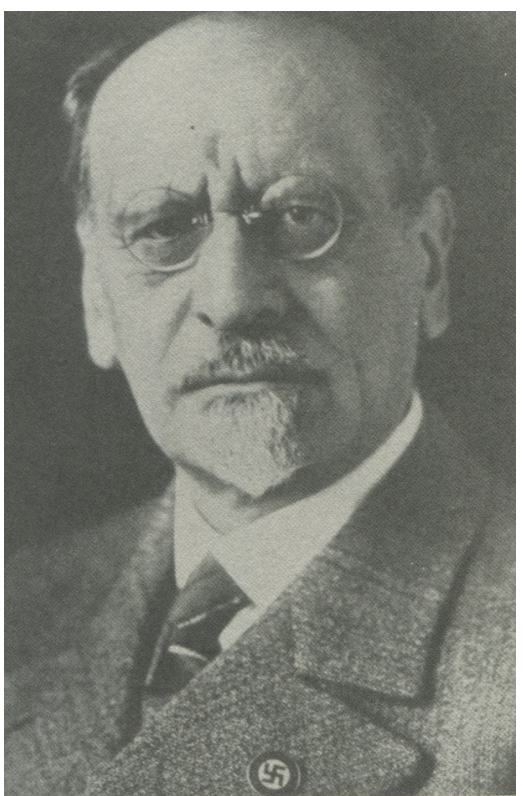

Plate 2: Alfred Lorenz (McClatchie, Analyzing Wagner's Operas)

Lorenz offered different explanations at different times concerning the end of his conducting activity at Coburg at the age of 52. On one occasion, he wrote that:

Since after the revolution the theater passed into other hands and circumstances for me became impossible, I made other arrangements and returned to my theoretical studies of music.

On a later occasion, Lorenz described the situation differently:

... shortly after the shift to the red system in 1920 I lost my "lifelong" appointment as General Music Director of the Theater Coburg-Gotha on account of my convictions. ${ }^{6}$

According to this second explanation, the reason for his early retirement lay beyond his control, due as it was to the "red system." Only after Hitler's seizure of power in 1933 did Lorenz send a letter to the Prussian Cultural Ministry in June of that year-a document now held in the collection of the Reichskanzlei-that offers a third explanation of what happened, whereby Lorenz depicts himself as a victim. What is claimed here is that after his long and meritorious contributions to the musical life of Gotha and Coburg he had been removed, in order to "make room for a Jew." Lorenz's claim is unconvincing, since his successor Ewald Lindemann was active during the time of National Socialism at various German opera houses, and must therefore have produced a proof of his Aryan background. In any event, Lorenz was successful with his strategy, and he remained at the Institute of Musicology at the Ludwig Maximilian University for fifteen years, from 1923 until 1938.

Lorenz took pride in his political activity and convictions. The files from the university archive

\footnotetext{
${ }^{6}$ The first statement is found in a c.v. (Lebenslauf) in the files; the second stems from a letter to the university administration, a document with the signature O-XIV-501.

${ }^{7}$ This letter from June 19, 1933 to the Prussian Cultural Ministry (Preussische Kultusministerium) is cited in Stephen McClatchie, Analyzing Wagner's Operas: Alfred Lorenz and German Nationalist Ideology (Rochester: University of Rochester Press, 1998), 7-8.
} 
convey an unambiguous picture of his ideological orientation. Lorenz stressed during the 1930s that already from before the beginning of the first World War he had been a member of the "German Union" (Deutschbund), an association that "already then promoted racial purity." On a form dated August 9, 1935 Lorenz attested his membership in the Deutschbund, which he described as a "thoroughly anti-Semitic organization" ("durchaus antisemitischer Verein"). Shortly before, on July 4, 1935, Lorenz wrote as follows to the Rektor of the university (Plate 3): ${ }^{8}$

As proof of my connection to the young spirit of the university and for my political convictions let me cite my date of entry into the NSDAP [National Socialist German Workers Party]: Nov[ember] 1931, as well as the fact that I for instance already held in 1933 a series of lectures on 'Race and Music'.

Heil Hitler!

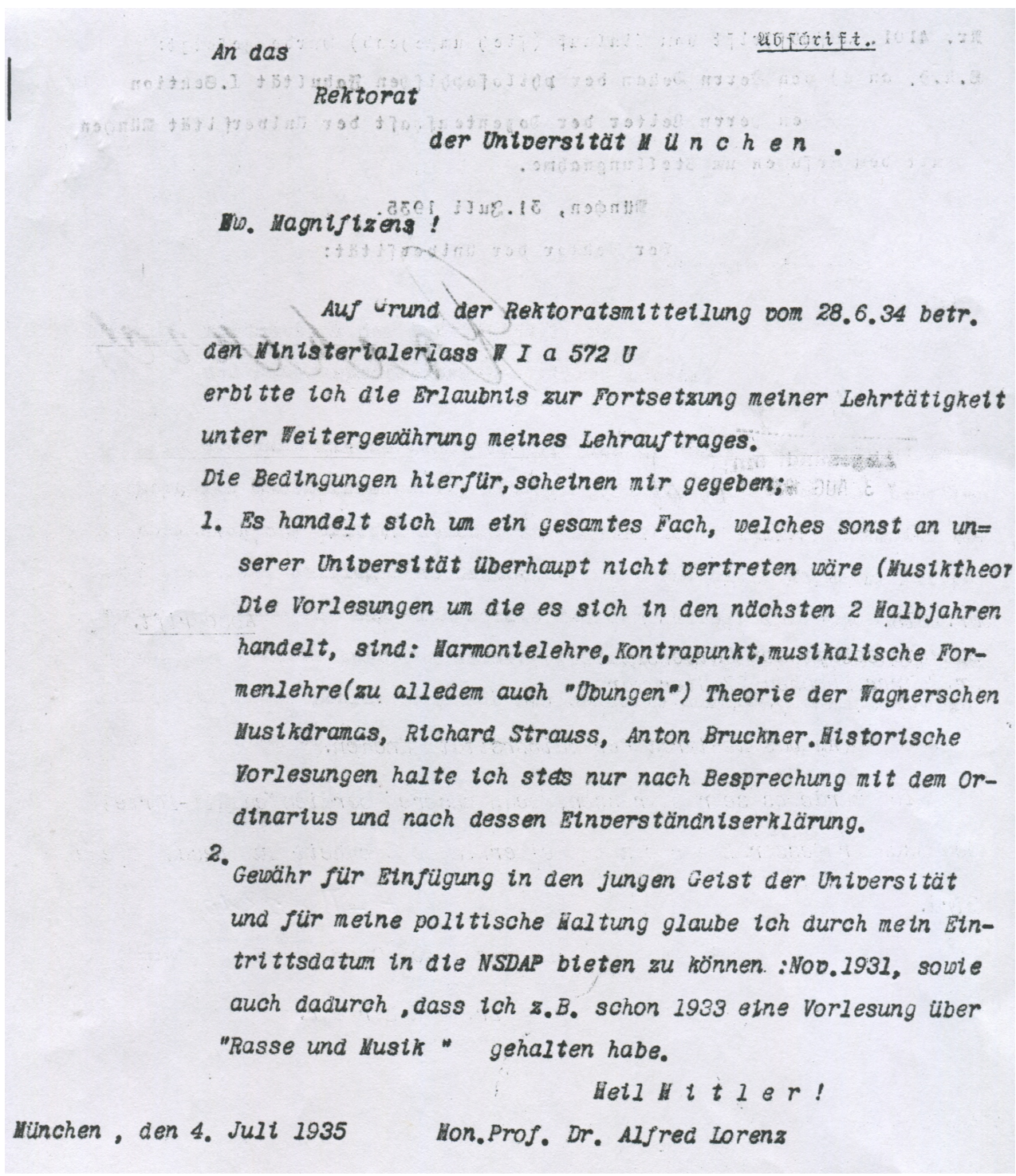

Plate 3 (from the University Archive of LMU Munich)

\footnotetext{
${ }^{8}$ Archive of the LMU Munich, document E-II-2316.
} 
Lorenz indicated as well that his son participated in the march to the Feldherrnhalle ["Field Marshal's Hall"] during the attempted Hitler Putsch in 1923. According to the files, Lorenz was the only professor at the university who belonged to the Nazi party before Hitler's rise to power.

Especially detailed is a communication from Lorenz to the dean of the Philosophical Faculty of the university from the beginning of 1939. Lorenz describes here how he took up his musicological studies in Munich beginning in 1920 and how he became at that time a "rapt follower" ("glühender Anhänger") of Hitler:

I took up again the musicological studies from my youth when I came to Munich, where I immediately began to attend the first Hitler gatherings and became his enthusiastic follower. It was the same with my family members, who followed me a year later, once I had succeeding in finding an apartment. The connection with the party was followed in accordance with National Socialist doctrine, whereby the future belongs to the youth; hence my son with my support immediately became a party member, and with my blessing he joined the march to the Feldherrnhalle. After circumstances were more settled (during the time of inflation we barely got by) we parents registered with the party in the middle of 1931 and received on 1 December the party books ...

In 1934 through the government cultural program ("Reichskulturbietung") a series of radio broadcasts were given about Richard Wagner, as part of which a major lecture of mine was broadcast from Breslau about "The Form of Wagner's Music Dramas." I gave a similar lecture on 29 October 1934 in Coburg. In addition, all of my other lectures (Würzburg, Vienna, Zürich, Basel, Bern, Stuttgart, Heidelberg, Mannheim, Karlsruhe, Leipzig, Köln, Berlin, Zwickau and Munich, courses abroad, etc. -) were given completely in service of the cultural perspective of National Socialism. ${ }^{9}$

Lorenz stresses how his activities as lecturer and teacher were committed to the cause of a National Socialist cultural perspective. His essays were by no means confined to the sphere of formal analysis of music. In 1933, he published an article in the Nazi journal Deutsches Wesen (German Essence) on "Richard Wagner's 'Parsifal' and National Socialism," and the articles of his later years carry such titles as "Musicology and Genealogical Research," "Musicology and the Jewish Question," "Musicology and Inherited Biology," as well as "Music Greets the Führer!"10

\section{Wagner Research and Ideological Blindness}

Lorenz's main contribution to Wagner research is his series of four volumes entitled Das Geheimnis der Form bei Richard Wagner (The Secret of Form in Richard Wagner), concerning the Ring cycle, Tristan und Isolde, Die Meistersinger von Nürnberg, and Parsifal. Do these volumes reflect Lorenz's ideological commitment, and if so, how is that manifested?

Lorenz's study of Parsifal is the fourth book in his series Das Geheimnis der Form bei Richard Wagner. His Parsifal appeared by the summer of 1933, auspicious timing for the so-called "new Germany" ("das neue Deutschland”) of National Socialism and for the Wagner Festival at Bayreuth, where Hitler's visit aroused much attention. Whereas Lorenz's first volume of Das Geheimnis der Form devoted to the Ring

\footnotetext{
${ }^{9}$ University Archive, Lorenz Akte, O-XIV-501.

10 "Musikwissenschaft und Ahnenforschung" appeared in December 1938 in the Zeitschrift für Musik; "Musikwissenschaft und die Judenfrage" was published that same month in Die Musik. "Musikwissenschaft und Erbbiologie" was published after Lorenz's death in 1940 in the Deutsche Militär-Musiker-Zeitung (May 25, 1940, 165-66); "Die Tonkunst grüsst den Führer!" appeared in the Zeitschrift für Musik 106 (1939), 355.
} 
appeared in 1924, marking the reopening of the Bayreuth Festival after a decade of closure, ${ }^{11}$ his last volume devoted to Parsifal coincided with the fulfillment of National Socialist ambitions.

The musical analyses of Lorenz are problematic. ${ }^{12}$ We shall return below to this issue. Let us first give attention to selected passages in Lorenz's Parsifal monograph. In the foreword, written in May 1933, he writes (with widely-spaced type for emphasis) that "Wagner conveyed his prophetic thoughts about leadership of the Führer and regeneration in his work and bequeathed thereby an exalted m is si o n.") ("Wagner hat seine prophetischen Gedanken über Führertum und Wiederaufstieg in diesem Werke ausgesprochen und ihm damit eine h o h e S e n d ung anvertraut." $)^{13}$

Elsewhere in his Parsifal book and in his essay "The Religion of Parsifal" ("Die Religion des Parsifal"), which appeared in February 1933 in the journal Die Musik, Lorenz expounds on the "new P a r s i f a 1 - R e 1 i g i o n." ${ }^{14}$ For him, Parsifal at the end of the opera not only restores the role Amfortas had held as Grail King but also inaugurates a new religion, signaling that "future of the German people" envisioned by Wagner in his "prophetic thoughts." From this perspective, Parsifal contains "the artistic depiction of an entire religion, even if not this in itself."

Important in this regard is Parsifal's raising up of the Holy Spear to the "marvelous upswing" of the musical motive that Lorenz designates as the "Erlösungswort" ("word of redemption"), which marks the final moments. For Lorenz, this affirmative close is crucial in conveying the "new Parsifal religion," enabling the listener to experience through the music the following insight, which is emphatically expressed in widely-spaced type on p. 153 of his book:

Wir sollen den Verfall überwinden und als rassisch hochgezüchtetes Volk zum Siege schreiten, will Wagner.

[We should overcome decay and as a racially high-bred people advance to victory, Wagnerwishes.]

Lorenz's words "Wagner wishes” are highly questionable; he even inserts a footnote to Wagner's essay "Religion und Kunst," to a passage that does not support his racist interpretation. For Lorenz, the theme of compassion (Mitleid) scarcely exists, but this idea is deeply embedded in Wagner's drama, as for instance in the Grail's prophecy of "Knowing through compassion, the pure fool," foreshadowing Parsifal's role. The thesis that Lorenz attributes to Wagner is undermined by the circumstance that Parsifal, differently than Amfortas, does not use the spear aggressively as a weapon, but instead as an instrument of healing. Noteworthy in this connection is that the Nazi ideologue Alfred Rosenberg, who was sentenced to death at the Nuremberg trials on account of crimes against humanity, held a different opinion than Lorenz: he found Wagner's Parsifal incompatible with National Socialist ideology, regarding the work as "a church-influenced enfeeblement in favor of the value of renunciation." 16

\footnotetext{
${ }^{11}$ Lorenz closes his foreword to the volume on the Ring with the words "summer 1924, the year of the reopening of the Bayreuth Festival” (Der musikalische Aufbau des Bühnenfestspieles 'Der Ring des Nibelungen' [Berlin: Max Hesses Verlag, 1924], vi). Hitler also visited the festival that year.

${ }^{12}$ Extensive discussion of the Wagner analyses of Lorenz is offered in my aforementioned study Wagner's 'Parsifal,' especially 198-203.

${ }^{13}$ Der musikalische Aufbau von Richard Wagners "Parsifal," foreword, dated May 1933. Emphasis in the original text.

${ }^{14}$ At the close of his essay Lorenz writes that “... the religion, that Wagner in his last work envisioned for the future of the German people ... is in no way of a pessimistic Schopenhauerian-Buddhist cast, but on the contrary while acknowledging suffering manifests willful strength and victorious heroism." ("Die Religion des Parsifal," Die Musik 5 [February 1933], 342347, quotation on 347).

15 "Die Religion des Parsifal," 347, 342, and the foreword to his Parsifal volume.

${ }^{16}$ Rosenberg, Der Mythus des 20. Fahrhunderts (Munich: Hoheneichen Verlag, 1930), 434.
} 
Lorenz's interpretation of the raised spear even seems reminiscent of the Wewelsburg project near Paderborn of the megalomaniac Heinrich Himmler, the Reichsfiuhrer of the Schutzstaffel (SS) — the most ideologically indoctrinated branch of the Nazi military responsible for many of the most terrible crimes against humanity. The triangular Wewelsburg castle was renovated with slave labor and intended to become the "middle point of the world;" its northern tower supposedly pointed toward Thule, the legendary place of origin of the Aryan race, which was regarded as most sacred ("Allerheiligstes") on the altar of National Socialist ideology. ${ }^{17}$ All of this is nonsense, but highly lethal nonsense.

To better understand the role of Lorenz at the Institute of Musicology at the Ludwig Maximilian University, we need to consider other persons who were then on the scene. How was it for the students of the Institute? What courses were offered, for instance, during the fall semester of 1934? On Wednesdays at 10:00 am one could choose between "Music and Race" with Lorenz or "Introduction to the Psychological Study of Folksong" with Kurt Huber. ${ }^{18}$ This is the Professor Huber who worked closely with Hans and Sophie Scholl and other members of the "White Rose" (Weiße Rose) resistance group, and who spoke with enthusiasm about the musical traditions of other peoples and races. ${ }^{19}$ Huber was born in Chur, Switzerland, in 1893 and studied musicology, psychology, and philosophy. Like the Munich musicologist Alfred Einstein but unlike Lorenz, Huber found that he could not complete a Habilitation with the Director of the Institute of Musicology, Adolf Sandberger. Huber came into contact with members of the "White Rose" group in 1942 and he was author of the sixth and final leaflet. ${ }^{20}$ He was beheaded on July 13, 1943.

Huber's viewpoint diverged very sharply from that of Lorenz. As Pamela Potter has observed,

Lorenz was fundamentally concerned to assert the musical superiority of the German race, and music psychology and especially the detailed study of "exotic music" had, in his opinion, been overestimated. He deemed the music of inferior races as inherently bad and called for an end to this fascination born of the false assumption that all races were equal. ${ }^{21}$

This is Lorenz's argument in his essay "Building Musicology," which appeared in the Zeitschrift für Musikwissenschaft in $1939 .{ }^{22}$ He fervently encouraged younger scholars to absorb racial ideology into their work, stressing anti-Semitic convictions in accordance with National Socialist doctrine. In this political context, Lorenz stood for narrowly "systematic" as opposed to "comparative" musicology, which was Huber's field of research.

Even after the death of Lorenz in 1939, Huber's work situation at the university cannot have been easy, in part because of the appointment in 1937 of Hans Alfred Grunsky, son of the Wagner scholar Karl Grunsky. The younger Grunsky was made professor of philosophy and psychology that year through the direct intervention of Adolf Hitler, an unprecedented act in the history of the institution. Grunsky was

\footnotetext{
${ }^{17}$ For more detailed discussion, see my study Wagner's'Parsifal,' esp. 32-36.

${ }^{18}$ Information about these courses at the Institute is found in Andreas Elsner, Zur Geschichte des musikwissenschaftlichen Lehrstuhls an der Universität München (Inaugural-Dissertation, LMU München, 1982), 534.

${ }^{19}$ For more information on these topics, see the following links on Huber: http://holocaustmusic.ort.org/politics-andpropaganda/third-reich/huber-kurt/ and on the "White Rose" resistance group: http://www.weisse-rose-stiftung.de/.

${ }^{20}$ For a recent discussion of Huber in relation to the "White Rose" group, see Yvonne Sherratt, Hitler's Philosophers (New Haven: Yale University Press, 2013), 207-28. More extensive discussion of Huber is offered in my chapter "Music Scholarship and Politics in Munich, 1918-1945," in This Thing Called Music: Essays in Honor of Bruno Nettl, ed. Victoria Lindsay Levine and Philip V. Bohlman (Lanham and Boulder: Rowman \& Littlefield, 2015), 102-12, esp. 106-8.

${ }^{21}$ Most German of the Arts: Musicology and Society from the Weimar Republic to the End of Hitler's Reich (New Haven and London: Yale University Press, 1998), 175; in German translation as Das deutscheste der Künste: Musikwissenschaft und Gesellschaft von der Weimarer Republik bis zum Ende des Dritten Reiches (Stuttgart: Klett-Cotta, 2000), 222.

22 "Musikwissenschaft im Aufbau”, Zeitschrift für Musikwissenschaft 65 (1939), 369.
} 
unqualified for the position, with dubious credentials and not having written a Habilitationsschrift. Like Hitler, Grunsky was inspired by having met Houston Stewart Chamberlain at Bayreuth. A document from May 26, 1937 confirms Grunsky's appointment as professor through Hitler's influence (Plate 4). A related document bearing the same date from the "Reichs- und Preussicher Minister für Wissenschaft, Erziehung und Volksbildung" in Berlin begins with the statement that "The Führer and Reichskanzler has named you as senior professor in a permanent position in the service of Bavaria" ("Der Führer und Reichskanzler hat Sie unter Berufung in das Beamtenverhältnis zum ordentlichen Professor im bayerischen Landesdienst ernannt.") $)^{23}$

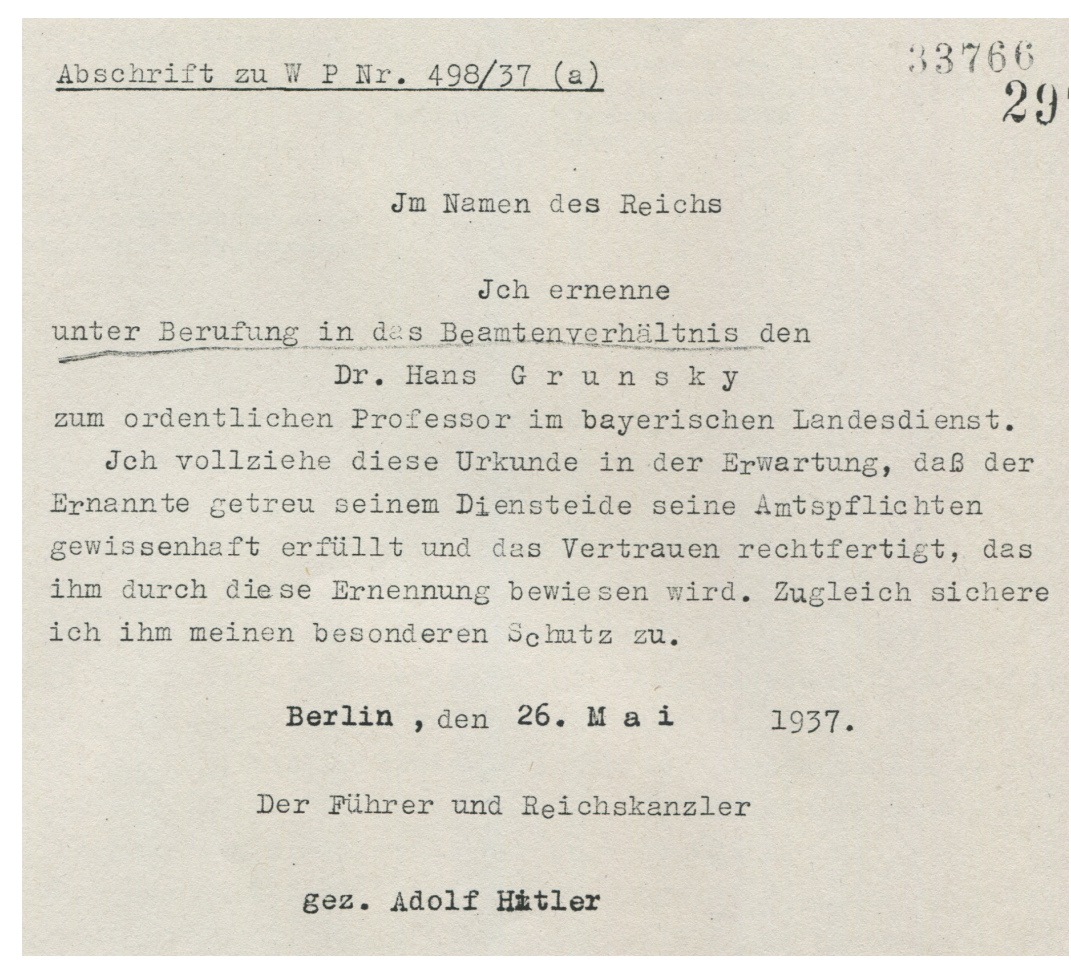

Plate 4 (from the University Archive of LMU Munich)

Once installed at the university in Munich, Grunsky showed himself to be a quarrelsome fanatic. His immediate task was to evaluate colleagues; any he identified as Jewish were promptly dismissed. He involved Winifred Wagner in his attempt to defame his philosophy colleague Herbert Cysarz for alleged "Jewishness," branding Cysarz's work with a yellow star, although that colleague was not of Jewish background. ${ }^{24}$

Hans Alfred Grunsky and his father Karl Grunsky published glowing reviews of the Wagner books of Alfred Lorenz during the 1920s and 1930s in various publications, as well as essays on Wagner in the Bayreuther Blätter and in the program books of the Wagner Festival, the Bayreuther Festspielfiuhrer. In 1935 Hans Grunsky published on "Wagner und Hitler" in the Nazi journal Deutsches Wesen. Hans Alfred Grunsky's success in gaining a professorship in Munich through Hitler's invention likely had to do with

\footnotetext{
${ }^{23}$ Both documents are held in the university archive file for Hans Alfred Grunsky bearing the signature E-II-1534.

${ }^{24}$ Grunsky's incompetence and quarrelsome behavior are documented in the university files with the signature O-XIV-586; a dismissive assessment of Grunsky is found in a letter from the Dekan Dr. Paul Lehmann to the university Rektor, dated January 23, 1950.
} 
Winifred Wagner's warm friendship with the Führer, and altogether with Hitler's close connections to Bayreuth. As we have seen, Grunsky had direct access to Winifred Wagner, and the elder Grunsky had long been active in the Bayreuth Circle.

In his detailed study of Lorenz, Stephen McClatchie comments that "the remarkable uniformity of critical opinion about Lorenz's work during his lifetime may be attributed to the then prevailing philosophical and aesthetic climate." 25 It was not, however, simply the "philosophical and aesthetic climate," but rather the brutal politics of the Third Reich that account for the overwhelmingly positive response to Lorenz's writings at that time. Lorenz had already embraced National Socialist ideology earlier, but from 1933 during the Hitler dictatorship, his work was practically immune from critique in Germany.

In an essay from November 1933 on "Richard Wagner as Musician" in the journal Wille und Macht (Will and Power), Lorenz scorned the "destructive liberal mish-mash" of "Jewish-influenced modern music," whereas on the other hand he found that Wagner's works embodied an "organic, communitybuilding National Socialist world perspective." Lorenz concluded that Wagner in his Gesamtkunstwerk achieved a marvelous unification of all arts, just as Hitler had succeeded in unifying the German people.

In the concluding section of his aforementioned essay on "Die Religion des Parsifal" from 1933, Lorenz writes that

Most important in this music is that the two main themes which are definitive for the new Parsifal-Religion - the Grail motive and the transformed version of the Communion themedisplay a completely rising, robust affirmative line without the slightest descent. It is thus conveyed to our feelings that the religion Wagner envisioned in his last work for the future of the German people ... manifests a thorough strength of will and victorious heroism. ${ }^{26}$

Lorenz regards the core meaning of the music drama as an embodiment of the religion of the German people striving toward victory.

One can hardly imagine a better example of the identification of Romantic art with political ideology according to a "metapolitical" model, such as was outlined by Peter Viereck already in the 1940s in his well-known book Metapolitics. ${ }^{27}$ Viereck saw a continuity and causality between German Romanticism in the cultural sphere on the one hand, and the rise of the National Socialist tyranny on the other, a development whose common roots lay in categories of evolutionary historicism and totalizing unity. If the case of Lorenz supports Viereck's thesis, this of course involves just one particular interpretation of Wagner's works, an interpretation which, however, surely had considerable currency during the period of National Socialism.

It comes therefore as no surprise that Hitler was depicted as a Parsifal-like figure in a poster from the time (Plate 5). No other Wagnerian drama offered a conclusion so well suited to glorification of a new leader replacing the old order. The Führer appears here bearing a Nazi flag while an eagle hovers. The eagle or Reichsadler in the poster is highly stylized, with a mechanized appearance, suggesting a military plane almost as much as a regal bird. The slogan "Es lebe Deutschland!" can be translated as "Long live Germany!" Light streaming from above identifies the leader as a "Lichtgestalt." 28

\footnotetext{
${ }^{25}$ Analyzing Wagner's Operas: Alfred Lorenz and German Nationalist Ideology (Rochester: University of Rochester Press, 1998), 178.

26 "Die Religion des Parsifal," Die Musik 5 (February 1933), 341-48.

${ }^{27}$ Viereck's book Metapolitics: From the Romantics to Hitler (New York: Knopf, 1941) was published in revised and expanded form as Metapolitics: The Roots of the Nazi Mind (New York: Capricorn, 1961, 1965) and most recently as Metapolitics: From Wagner and the German Romantics to Hitler (New Brunswick, NJ: Transaction, 2004).

${ }^{28}$ More detailed discussion of this poster and a comparison to the Parsifal depictions of Franz Stassen is offered in my book
} 


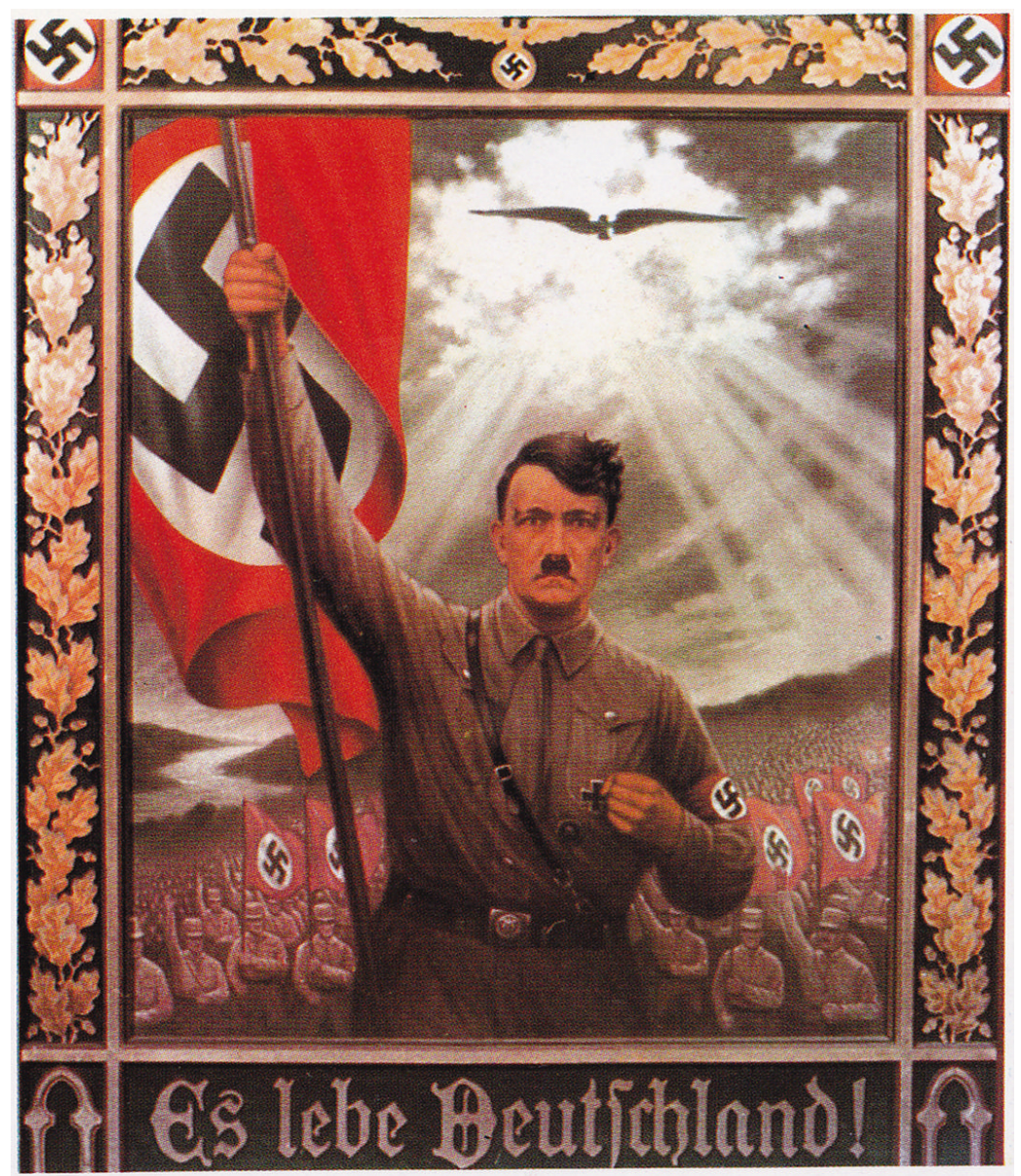

Plate 5

Lorenz's interpretative move in identifying Hitler as Parsifal in his Parsifal book was not an original idea but an assimilation of propaganda in broader circulation, propaganda that Houston Stewart Chamberlain helped set into motion by hailing Hitler as a "god-sent benediction" to Germany nine years earlier. For Chamberlain, Hitler was a rare example of a "luminous figure" ("Lichtgestalt"), and a "w a h r e r V o l k s m e n s c h" ("true human being of the people"), ${ }^{29}$ symbolic qualities reflected in the poster in the form of the downward-streaming light and the massive community of brown-shirted followers bearing Nazi flags and placed in a landscape suggestive of the Rhine Valley.

A compulsion toward a comprehensive yet schematic unity at the cost of a colorful differentiated reality can often be observed in the detailed musical analyses of Lorenz. Carl Dahlhaus examined the analyses of Die Walküre und Das Rheingold in an essay from 1965 on "Wagner's Concept of the PoeticMusical Period," finding not a single analysis free from artificiality and misrepresentation. Lorenz employed the concept of the "poetic-musical period"-which appears only once in Wagner's writings, in his treatise Oper und Drama - as the basis for his analytic method. Lorenz's attempt to segment Wagner's works according to this periodic framework is questionable in part because the boundaries between the

Wagner's 'Parsifal', 24-25, 293-96.

${ }^{29}$ These phrases are contained in Chamberlain's leaflet hailing Hitler from January 1, 1924 (emphasis in the original text), reproduced in Hartmut Zelinsky, Richard Wagner. Ein deutsches Thema. Eine Dokumentation zur Wirkungsgeshcichte Richard Wagners 1876-1976 (Berlin and Vienna: Medusa, 1983), 170. 
periods are so often arbitrary. This kind of segmentation may have been pragmatically useful for Lorenz in conducting performances, but it displays grave weaknesses when adopted as an analytical method. In a more recent assessment of this issue from 2002, Werner Breig concluded about the concept of the "poeticmusical period" that "as a technical term for formal divisions in Wagner's musical dramatic works beginning with the Ring cycle. . it is not viable." 30

How does Lorenz analyze for instance the big scene in the last act of Götterdämmerung (The Twilight of the Gods), with Siegfried's final narrative leading to his restored memory of Brünnhilde and his ensuing murder at the hands of Hagen? For Lorenz, these extended sections of the drama form a so-called "period in A major." In his detailed overview, Lorenz recognizes a three-part arch (Bogen) form. Yet no more than 25 measures of this section's 145 measures are in A major. Lorenz comments that this period "displays extreme freedom" ("in dieser P. [eriode] herrscht höchste Freiheit"); he experienced difficulty, despite the pseudo-scientific framework of his methodology, in uncovering the "secret of form" in this part of Wagner's drama. ${ }^{31}$ Yet Lorenz overlooks crucial form-building aspects, such as how Wagner's treatment of Siegfried's final narrative and death involves a varied musical recapitulation of extended passages drawn from the second and third acts of the preceding drama Siegfried, whereby Siegfried's restored memory of Brünnhilde's awakening serves as the focal point of a tonal duality between E major and C major, followed by a tragic turn to $\mathrm{C}$ minor in the ensuing funeral march. This recapitulatory complex is arguably the single largest formal synthesis in all of Wagner's works. ${ }^{32}$

The notion of a seamless, systematic periodic succession was a mania in Lorenz's historical work as well, such as in his book Abendländische Musikgeschichte im Rhythmus der Generationen (Western Music History in the Rhythm of Generations) from 1928. This study takes as its foundation the Generationslehre (Doctrine of Generations) stemming from Alfred Lorenz's father, Ottokar Lorenz, a pioneering figure of racial theory. A guiding concept here involves periods of precisely three centuries in duration, which make up in turn ten generations of thirty years each. Inasmuch as Lorenz regards the development of music as based upon two opposing principles, "homophonic rhythm" and "polyphonic introspection," he reduced, as Pamela Potter writes, "music history to a pattern of alternating influence of one principle over the other, climaxing every three centuries." 33

At the Institute for Musicology of the Ludwig Maximilian University Alfred Lorenz was successful. He enjoyed the support of the institute's director, Professor Adolf Sandberger, who was also keenly interested in Wagner and had in 1888 as a young man published an article on Wagner's first opera Die Feen (The Fairies), a study in which however the strong influence of the Venetian dramatist Carlo Gozzi is conspicuously marginalized. ${ }^{34}$ On the other hand, the far better qualified Munich musicologist Alfred

\footnotetext{
${ }^{30}$ See in this regard Dahlhaus, "Wagners Begriff der 'dichterisch-musikalischen Periode," in Beiträge zur Geschichte der Musikanschauung im 19. Fahrhundert, ed. Walter Salmen (Regensburg 1965), 179-87; and Breig, "Wagners Begriff der 'dichterisch-musikalischen Periode'," in "Schlagen Sie mir die Kraft der Reflexion nicht zu gering an.” Beiträge zu Richard Wagners Denken, Werk und Wirken, ed. Klaus Döge, Christa Jost, and Peter Jost (Mainz: Schott, 2002), 158-72.

${ }^{31}$ Lorenz, Der musikalische Aufbau des Bühnenfestspieles 'Der Ring des Nibelungen' (Berlin: Max Hesses Verlag, 1924$), 202$.

${ }^{32}$ For a detailed discussion, see my essay "Dramatic Recapitulation in Wagner's Götterdämmerung," in $19^{\text {th }}$ Century Music 4 (1980), 101-12, reprinted in: National Traditions in Nineteenth-Century Opera, 2, ed. Michael C. Tusa (Surrey: Ashgate, 2010), 157-68.

${ }^{33}$ Potter, Most German of the Arts: Musicology and Society from the Weimar Republic to the End of Hitler's Reich (New Haven and London: Yale University Press, 1998), 170-71.

${ }^{34}$ The entire basis for Wagner's drama is Gozzi's La donna serpente. Sandberger's nationalistic orientation likely discouraged more balanced acknowledgement of Gozzi's role. See Sandberger, "Richard Wagner in Würzburg: Die Hochzeit, Die Feen" in Neue Zeitschrift für Musik (1888), reprinted in Richard Wagner: Die Feen, ed. Michael von Soden and Andreas Loesch (Frankfurt am Main: Insel Verlag, 1983), 176-97.
} 
Einstein encountered difficulties at the Musicological Institute. Potter comments about Einstein that

As the foremost expert on the Italian madrigal and the works of Mozart, his skill and productivity were so widely respected that he was entrusted with the responsibilities of editing $Z f M w$ [the Zeitschrift für Musikwissenschaft], revising Riemann's Musiklexikon, and enlarging and correcting Köchel's catalogue of Mozart's works. Despite these outstanding scholarly achievements, he was systematically excluded from securing an academic position, from the time he earned his doctorate in 1903 until his forced emigration in 1933. He was not allowed to proceed with his Habilitation because his doctoral advisor, Adolf Sandberger, refused to endorse him. Einstein was convinced that Sandberger was motivated by anti-Jewish feelings, and he believed that Sandberger recommended him as general editor of the $Z f M w$ only to ease the guilt he felt over ruining his student's career. ${ }^{35}$

Much later, in 1950, Einstein was interviewed by Time magazine in America. The article concludes with the comment that "by chasing him out of his rut and back to work as a master mason in music scholarship, Adolf Hitler, [Einstein] says, became 'my greatest benefactor'.”36

In 1947, two years after the end of the war, the dean and music professor Rudolf von Ficker was entrusted with the task of evaluating Lorenz's political activity during the Third Reich. Ficker downplayed the issue, classifying Alfred Lorenz as "at most a fellow traveler" ("höchstens als Mitläufer einzustufen") (Plate 6). There were several different categories of involvement or guilt: 1) primary guilt ("Hauptschuldige”), 2) guilty ("Belastete”), 3) less responsible (“Minderbelastete'), 4) fellow travelers ("Mitläufer"), and 5) innocent ("Entlastete").

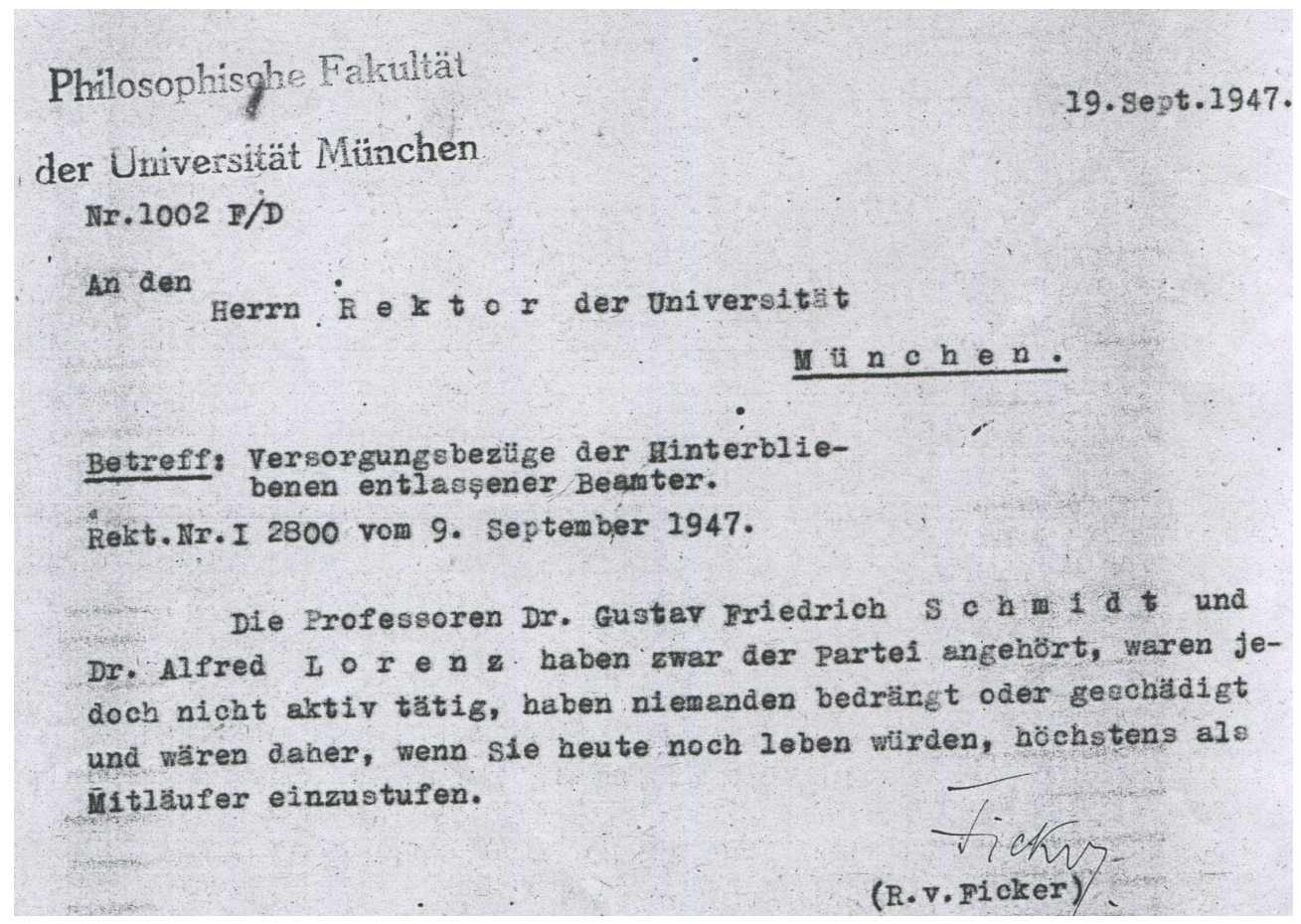

Plate 6 (from the University Archive of LMU Munich)

\footnotetext{
${ }^{35}$ Potter, Most German of the Arts: Musicology and Society from the Weimar Republic to the End of Hitler's Reich, 97; in German edition as Das deutscheste der Künste: Musikwissenschaft und Gesellschaft von der Weimarer Republik bis zum Ende des Dritten Reiches, 132.

36 “A Star of Knowledge," Time, April 24, 1950.
} 
What would have Lorenz thought about this? Would he not have felt misrepresented or betrayed? The category of "fellow traveler" or "Mitläufer" does not fit to this proud, eager, even indefatigable pioneer of racist National Socialist doctrine, as von Ficker certainly very well knew. ${ }^{37}$ Ficker, who had served as Director of the Institute of Musicology as the successor of Sandberger since 1931, described Lorenz in 1940 as "the oldest champion of Adolf Hitler."

Ficker's judgement on the document shown about Lorenz's colleague, Professor Gustav Friedrich Schmidt as "not active" and to be classified as "at most as "fellow traveler" is conspicuous as well. Potter offers a brief description of Schmidt's activity:

Gustav Friedrich Schmidt, also on the Munich musicology faculty, had been head of the organization "Kulturwacht" ("Culture Watch") in 1931, an organization dedicated to "the intellectual struggle ["geistigen Abwehrkampf"] against the destruction of our Western culture [Zersetzung unserer abendländischen Kultur"]." He joined the Nazi party in 1933 and composed "Der Führer rief! Ein deutsches Kampf- und Treuschwurlied," ("The Führer Calls! A German Song of Struggle and Pledge"), dedicated to Adolf Hitler and acknowledged by the Reich Chancellery. ${ }^{38}$

Numerous "Struggle and Pledge" or "Swearing of Allegiance" songs and patriotic "Führer Cantatas" were produced at this time-an entire propagandistic wave—and in that context we can regard Lorenz's forced ideological interpretation of the end of Parsifal as a kind of "Swearing of Allegiance" close (Treuschwurschluss), signaling (in his words) the "willful strength and victorious heroism" of the German people, even if much in Wagner's work contradicts this interpretation.

The use of such terms as "intellectual struggle" ("geistigen Abwehrkampf") against "destruction of our Western culture" ("Zersetzung unserer abendländischen Kultur") is unsettling in relation to a muchdiscussed passage from Hans Heinrich Eggebrecht's book Musik im Abendland (Western Music), in which he writes as follows:

Abendländisch ist ... eine Form des Daseins und eine Prägung des Denkens ... die besonders dann als abendländisch ins Bewusstsein traten, wenn sie geschichtlich etwa durch islamische, osmanische, heidnische, barbarische oder durch extrem materialistische, entseelt zivilisatorische, zerstörerisch technische Kräfte bedrängt und bedroht wurden. ${ }^{39}$

[Western is ... a form of being and manifestation of thought ... that especially comes into focus as Western when it is historically confronted by Islamic, Osmanic, heathen, barbaric [influences] or threatened through extremely materialistic, soulless, destructive technical forces.]

Relevant here is the discovery by Boris von Haken that Eggebrecht as a young junior officer belonged to a commando unit [Feldgendarmerie-Einheit] that committed mass murder of Jews in the Crimea in December $1941 .^{40}$ In this connection, the term "Abendland" ("Western") used in association with a struggle against enemies is reminiscent of numerous such examples from the period of National Socialism. ${ }^{41}$

\footnotetext{
${ }^{37}$ As Potter observes, one motivation for posthumous clemency was to allow family members of faculty to receive continued access to pensions (Most German of the Arts: Musicology and Society from the Weimar Republic to the End of Hitler's Reich, 248).

${ }^{38}$ Potter, Most German of the Arts, 102; Das deutscheste der Künste, 138.

${ }^{39}$ Eggebrecht, Musik im Abendland. Prozesse und Stationen vom Mittelalter bis zur Gegenwart (München: Piper, 1998), 36-37.

${ }^{40}$ See "Im Herzen das grösste Grauen," Zeit Online, July 11, 2013; and "NS-Kriegsverbrechen: Spalier am Mördergraben,” Die Zeit, December 17, 2009. The case of Eggebrecht has received much attention since 2009.

${ }^{41}$ Hitler, in a telegram to commanding general Paulus in Stalingrad on January 24, 1943, wrote how "the army ... through its heroic fortitude [made] an unforgettable contribution to the support of the defensive front and the rescue of the West ("Abendland"). The original text is as follows: "die Armee ... durch ihr heldenhaftes Ausharren einen unvergesslichen
} 
Ficker's 1947 judgement about Lorenz and Schmidt resonates as well with a 2009 article in the Süddeutsche Zeitung in Munich about murder cases allegedly committed by an SS member, entitled "In Doubt for the Accused," attesting that "the impression arises that the process of justice serves the victims less than the accused." ${ }^{2}$

That brings us at last to Thomas Mann's weighty lecture of 10 February 1933 on "The Suffering and Greatness of Richard Wagner," a lecture held before an audience of 500 listeners in the Auditorium Maximum of the Ludwig Maximilian University, a space adjacent to the Musicological Institute. Mann's critically differentiated, artistically nuanced interpretation of Wagner's works deserves respect and remains relevant. A point of emphasis in his interpretation lies in the recognition of the cosmopolitan character of this artistic legacy. Toward the end of Mann's text is a passage missing from the original typescript of the Munich lecture, which is held at Yale University, a passage which must therefore have been inserted into his text. ${ }^{43}$ In these sentences, Mann stresses that

Es ist durch und durch unerlaubt, Wagners nationalistischen Gesten und Anreden den heutigen Sinn zu unterlegen - denjenigen, den sie heute hätten. Das heißt sie verfälschen und mißbrauchen, ihre romantische Reinheit beflecken.

[It is absolutely unallowable to attribute to Wagner's nationalistic gestures and statements a contemporary meaning - the meaning, that they would have today. This is to falsify and misuse them, to soil their romantic purity.]

Mann's standpoint is thus precisely the opposite of Lorenz, who emphasized Wagner's so-called "prophetic thoughts about leadership of the Führer" ("prophetische Gedanken über Führertum”). That Thomas Mann's lecture served as a pretext for the so-called "Protest der Richard-Wagner-Stadt München" casts light on the catastrophic circumstances in the cultural life of the city at that time. Sadly, the "Protest" stemmed not from party hacks but from distinguished musicians, especially the conductor Hans Knappertsbusch in association with the composer Hans Pfitzner. ${ }^{44}$ Thomas Mann was by that time well known as a long-standing defender of the Weimar Republic and opponent of the National Socialists. ${ }^{45}$ The world-renowned novelist and Nobel prize-winner Thomas Mann was threatened with possible deportation to Dachau and forced into exile, while the blinded fanatic Alfred Lorenz, who promoted the dissemination of the National Socialist cultural program, received high respect. This is doubtless a nadir, probably the lowest point altogether, in the history of Wagner reception.

Wagner reception is-not unlike his artworks-a genuinely complicated subject. I first intended to concern myself just with the first period of this reception history, stretching from the composer's death in 1883 until 1945-embracing the period in which Lorenz played a leading role-but I have become deeply drawn into the historical developments that form the background of Wagner reception, and with which

\footnotetext{
Beitrag zum Aufbau der Abwehrfront und der Rettung des Abendlandes [leistet]" (Richard Faber, Abendland. Ein politischer Kampfbegriff [Beroin: Philo Verlagsgesellschaft, 2002], 34). SS members often made use of the "Abendland" vocabulary. (Dagmar Pöpping, Abend. Christliche Akademiker und die Utopie der Antimoderne [Berlin: Metropol Verlag, 2002], 9).

42 "Im Zweifel für den Täter," Süddeutsche Zeitung, October 27, 2009.

${ }^{43}$ The typescript of Mann's lecture is held at the Beineke Library, Yale University. Mann's lecture existed from the outset in an extended version, which was first published in April 1933 in Die neue Rundschau. See Mann, Im Schatten Wagners: Thomas Mann über Richard Wagner. Texte und Zeugnisse 1895-1955, ed. Hans Rudolf Vaget (Frankfurt am Main: Fischer, 2005), 87$143,280$.

${ }^{44}$ See in this regard especially Hans Rudolf Vaget, Seelenzauber: Thomas Mann und die Musik (Frankfurt am Main: Fischer, 2006), 327.

${ }^{45}$ A recent contribution on this topic is Sebastian Hansen's Buch Betrachungen eines Politischen. Thomas Mann und die deutsche Politik 1914-1933 (Düsseldorf: Wellem, 2013).
} 
the Musicological Institute is almost fatefully connected. To explore these matters was originally not my intention, and others have clarified many of the basic facts.

A scholarly obligation to impartiality does not permit an assessment of the impact of Alfred Lorenz on Wagner reception to be divorced from its context and its connections to persons and institutions. After all that has been said, I refer of course to the unmerited and sometimes still overestimated role of Lorenz in the reception of Wagner. ${ }^{46}$

It should touch us all. A theoretically- and practically-trained 30-year-old musician begins a career as conductor and holds this position—apparently quite successfully—for 22 years, a highly promising basis for his commitment at a ripe stage of life to musicological studies. What transpired? A life path, which seemed consequent and fruitful from Lorenz's viewpoint, but from a broader perspective can only be understood as flawed and mistaken.

\begin{abstract}
The career of Alfred Lorenz, who published four analytical studies of Wagner's works between 1924 and 1933, merits reevaluation based on documents held in the archives of the Ludwig Maximilian University in Munich. Lorenz was passionately committed to National Socialism, and proudly joined the party before Hitler's rise to power. During the 1930s, Lorenz published numerous propagandistic essays advocating Nazi ideology and racial purity. Similarly, in his still-overestimated study of Parsifal, Lorenz claims to perceive Wagner's "prophetic thoughts about leadership of the Führer," identifying the redeemer-figure Parsifal with Hitler, leader of "New Germany" at the outset of the Third Reich.
\end{abstract}

\footnotetext{
${ }^{46}$ The overestimation of Lorenz's work has roots in the close-knit German nationalist circles described above, but a prominent British author like Gerald Abraham, writing in 1938, praised Lorenz's contribution as "masterful" and as "great analytical work" (A Hundred Years of Music [London: Duckworth, 1955; first published 1938], 121, 128). In his chapter from 1999 on "Wagners Kompositionstechnik" in his edited book Richard Wagner. Konstrukteur der Moderne, Claus-Steffen Mahnkopf writes that "Lorenz's large studies ... are a milestone of research on Wagner's music and remain unsurpassed." ("Lorenz' grosse Abhandlungen ... sind ein Meilenstein der Forschung zu Wagners Musik und bis heute uneingeholt.”) (p. 166).
} 